\title{
Novelas, cuplés, postales y cine: una aproximación a las representaciones erótico-pornográficas durante la Segunda República Española
}

\section{Novels, cuplés, postcards and cinema: an approach to erotic-pornographic representations during the Second Spanish Republic}

\author{
Carmen GUILLÉn LORENTE \\ Universidad de Murcia \\ carmen.guillen@um.es \\ http://orcid.org/0000-0003-4727-8539
}

Fecha de recepción: 12-06-2020

Fecha de aceptación: 16-07-2020

\section{RESUMEN}

El presente texto analiza el incremento experimentado por las representaciones eróticopornográficas durante la Segunda República al hilo de las particularidades contextuales de apertura que tuvieron lugar entonces. La hipótesis de trabajo sitúa el esplendor de la sicalipsis española en este periodo favorecido por un escenario político permisivo que aumentó la edición de dichas publicaciones. A partir de la prensa y la literatura de la época se examina en primer lugar el paisaje cultural español atendiendo, específicamente, al desarrollo de la sexología como expresión del interés suscitado por el binomio sexo/sexualidad. A continuación, se estudiará el surgimiento y desarrollo de la noción pornografía discurriendo por su complejidad terminológica para, finalmente, indagar en todo el espectro de representaciones pornográficas que entonces comprendían la fotografía, el cine, la novela sicalíptica, las revistas licenciosas y el teatro.

Palabras clave: pornografía, cine, teatro, fotografía, literatura

Topónimo: España

Periodo: Segunda República

\section{ABSTRACT}

This essay analyses the increase in erotic-pornographic representations during the Spanish Second Republic. The working hypothesis situates the apogee of Spanish pornography during these years, favoured by a political scenario that allowed for the proliferation of publications of this nature. There is examination of the development of sexology as an expression of the interest aroused by the sex / sexuality binomial. There is also analysis of the development of the notion of pornography and, finally, investigation of the entire spectrum of pornographic representations which, at that time, included photography, cinema, erotic novels, licentious magazines and theatre. 


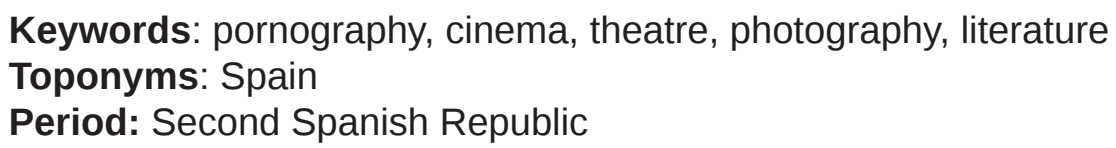

\section{INTRODUCCIÓN}

Reflexionar sobre la sexualidad humana implica adentrarnos tanto en la función reproductora como en la cuestión erótica; su estudio se sitúa, en consecuencia, entre el ámbito médico, biológico y cultural ofreciendo enormes posibilidades analíticas. En la actualidad, la bibliografía desde estos y otros espacios ofrece un panorama historiográfico cada vez más completo que permite entender la complejidad de la sexualidad humana a través de una perspectiva, hasta no hace demasiado, desconocida ${ }^{1}$. Pero no siempre ha sido así; su estudio se ha visto ensombrecido por cuestiones religiosas, morales o, puramente, tendenciosas, que según el periodo histórico condicionaron los avances teóricos en esta materia.

Desde finales del siglo XIX, los comportamientos humanos en la alcoba cobraron un interés inusitado, de modo que los discursos médicos y divulgativos sobre el aborto, el control de la natalidad, la supuesta patología homosexual, o las diferencias entre sexualidad femenina y masculina fueron cuestiones ampliamente debatidas ${ }^{2}$. Paralelamente a estos discursos teóricos, se había ido experimentando también una difusión sin precedentes de las imágenes cuyo contenido giraba en torno al sexo, dando lugar al nacimiento del concepto pornografía ${ }^{3}$. Como explica Bernard Arcand, pese a que el siglo XIX es descrito como un período de censura donde reina el puritanismo burgués, en realidad, se produce en occidente una enorme expansión de la producción pornográfica que marcará el principio de su consumo masivo y universal ${ }^{4}$. Con estos precedentes, el siglo $X X$ se revela como un periodo de auge de la sexualidad ${ }^{5}$ a nivel científico, pedagógico y, al mismo tiempo, la representación gráfica o artística del sexo inicia su comercialización como objeto de deseo y fuente de excitación.

El presente ensayo analiza el incremento experimentado por las representaciones erótico-pornográficas durante la Segunda República al hilo de las particularidades contextuales de apertura que presentó este periodo. La hipótesis de trabajo sitúa el esplendor de la sicalipsis española en este periodo al verse favorecida por un escenario político -

1 J. L. Guereña (coord.), La sexualidad en la España contemporánea (1800-1950), Cádiz, Universidad de Cádiz, 2011; Un infierno español. Un ensayo de bibliografía de publicaciones eróticas clandestinas españolas (1812-1939), Madrid, Libris, 2011; Detrás de la cortina. El sexo en España (1790-1950), Madrid, Cátedra, 2018; M. Zubiarre, Culturas del erotismo en España (1898-1939), Madrid, Cátedra, 2015.

2 La sexología se consolida como disciplina científica a finales del siglo XIX gracias a los trabajos de Ellis, Bloch y Hirshfeld, sentando las bases que, en siglo XX, desarrollarían las investigaciones de Kisney y Masters y Johnson. Véase, E. Amezúa, "Cuestiones históricas y conceptuales. El paradigma del hecho sexual, o sea de los sexos, en los siglos XIX y XX", Anuario de Sexología, 4, (1998), p. 5-19.

3 Sobre el concepto pornografía véase, J. F. Malem, "Acerca de la pornografía", Revista del Centro de Estudios Constitucionales, 2, (1992), p. 217-239.

4 B. Arcand, El jaguar y el oso hormiguero. Antropología de la pornografía, Buenos Aires, Nueva Visión, 1993, p. 144, citado por M. Rodríguez, Prácticas postporno en el Estado español. Políticas y estéticas de representación y acción, Tesis Doctoral dirigida por Emilia María Durán Almarza, Universidad de Oviedo, 2017, p. 34.

5 M. Foucault, Historia de la sexualidad. La voluntad de saber, Buenos Aires, Siglo XXI, 2006, p. 25-47. 
abandono de las posturas más moralistas - y tecnológico —abaratamiento de la imprenta, expansión de la fotografía_ que permitió proliferar las publicaciones de esta índole. A partir de la prensa y la literatura de la época se examina, en primer lugar, el paisaje cultural español atendiendo, específicamente, al desarrollo de la sexología como expresión del interés suscitado por el binomio sexo/sexualidad. A continuación, se analiza, el surgimiento y desarrollo de la noción pornografía discurriendo a través su complejidad terminológica, para finalmente indagar en todo el espectro de representaciones pornográficas que entonces comprendían no solo la fotografía o el cine, sino también la novela corta sicalíptica, las revistas licenciosas y el teatro.

\section{BREVE APROXIMACIÓN A LA MARCHA TRIUNFAL DEL SEXO6}

Durante las primeras décadas del siglo XX en España se inicia un creciente interés pedagógico, médico y divulgativo por la sexualidad que termina de cristalizar en la Segunda República7. La agitación cultural y científica de aquel periodo tuvo como principal objetivo sentar las bases de una profunda transformación de los paradigmas sexuales establecidos y analizarlos desde una discursiva diferente a la que se venía haciendo. Este proceso debe entenderse desde una doble perspectiva: de un lado, en el marco de una tendencia internacional en la que la literatura científico popular sobre sexualidad había acusado un importante crecimiento; de otro, como reacción al pensamiento tradicional que hasta entonces había sido el hegemónico. No debemos olvidar que el contexto social y político de la España de principios del siglo XX estaba fuertemente influenciado por los preceptos del ideario católico, en el que la represión sexual era uno de sus ejes fundamentales. De hecho, fue el momento en el que surgieron instituciones como las Ligas contra la pública inmoralidad $^{8}$ o el Real Patronato para la Represión de la Trata de Blancas ${ }^{9}$, dentro de una corriente de vigilancia y control de la sexualidad, en especial de la femenina. Al mismo tiempo, y en contrapartida, tuvieron lugar una serie de iniciativas institucionales como la creación de la Sociedad española de abolicionismo (1922) ${ }^{10}$ o el Instituto de Medicina social de Madrid (1919) ${ }^{11}$ al calor de las ideas europeas más progresistas. Las dos mentalidades políticas tuvieron así su reflejo en el plano de la sexualidad donde se desencadenó un

6 "La Revista Estudios publica en 1933 un breve pero substancioso artículo, con el significativo título 'La Marcha triunfal del sexo' en el que su autor, Llaucadé, hace un análisis del fenómeno un nuevo: la irresistible ascensión de las obras científicas y pedagógicas sobre temática sexual en el mercado editorial", en E. Amezúa, "Los hijos de don Santiago. Paseo por el casco histórico de la sexología", Revista Española de Sexología, 59-60, (1993), p. 89.

7 "Gobernada hasta el advenimiento de la república por autócratas que comerciaban con la ignorancia del pueblo, [España] ha despertado y se ha encontrado, entre mil problemas a resolver, el de la sexualidad", en A. Peratoner, Los órganos genitales y el amor en las religiones, citado por J. L. Guereña, Detrás de la cortina..., p. 93.

8 "Barcelona sería la pionera fundando en 1918 la primera Liga contra la pública inmoralidad. Tras el golpe de estado de Primo de Rivera aumentaría la creación de este tipo de agrupaciones en varias ciudades españolas como Valencia, Alicante o Valladolid", en C. Guillén, El Patronato de Protección a la Mujer: prostitución, moralidad e intervención estatal durante el franquismo, tesis doctoral dirigida por Carmen González y Encarna Nicolás, Universidad de Murcia, 2018, p. 155.

9 "Su principal función fue la vigilancia y tutela de menores para cuyo fin se establecieron 52 delegaciones, una en cada capital de provincia", Ibídem, p. 69.

10 "Real Orden de 27 de marzo de 1930" en, Gaceta de Madrid, 28-III-1930.

11 R. Álvarez, "El Instituto de Medicina Social, primeros intentos de institucionalizar la eugenesia", Asclepio: Revista de historia de la medicina y de la ciencia, 40, (1988), pp. 343-358. 
enfrentamiento dialéctico entre las posturas conservadoras y las promotoras de "una modernidad sexual inseparable del necesario cambio social"12.

Al inicio de la Segunda República se votó una nueva Constitución que tejió los mimbres del tránsito hacia la modernidad. En este sentido, la segunda experiencia republicana conseguía alumbrar una serie de transformaciones que atravesaron todos los sectores de la sociedad e implementaron los aspectos definitorios de la modernidad de un Estado como son la democratización o la laicidad ${ }^{13} \mathrm{y}$, en el plano personal, se aprobaron reformas tan significativas como la ley de divorcio ${ }^{14}$ o la despenalización del aborto ${ }^{15}$. La legislación republicana consiguió aliviar, además, la carga tradicional sobre la mujer, principalmente al diluir el poder de la Iglesia como instrumento de control sobre las costumbres y los cuerpos femeninos ${ }^{16}$. Esas transformaciones en el terreno legislativo implicaron asimismo algunas novedades en relación al pensamiento oficial y a la salud pública.

Desde este horizonte aperturista y renovado es dónde debe entenderse el interés hacia la sexualidad plasmado en diferentes publicaciones del ámbito de la literatura y la prensa y que, académicamente, ha recibido el nombre de "reforma sexual"17. Este concepto fue introducido en los primeros años del siglo XX por los sexólogos de la primera generación para convertirse a partir de 1932 en un movimiento organizado bajo el nombre de Liga Española para la Reforma Sexual sobre bases científicas, filial de la Weltliga für Sexualreform fundada en 1928 en Berlín ${ }^{18}$. Dicho organismo consiguió organizar las Primeras Jornadas Eugenésicas Españolas ${ }^{19}$ tras un primer intento que sería suspendido en 1928 por el gobierno de la dictadura primoriverista alegando que promovía el "regodeo pornográfico"20. La Liga, que tuvo como principal medio de divulgación la revista Sexus, estuvo presidida al inicio por Gregorio Marañon, una de las personalidades claves en la sexología española. Sus Tres ensayos sobre la vida sexua/21 tuvieron un enorme impacto en el debate sobre la identidad sexual ${ }^{22}$, principalmente a través del desarrollo de su teoría sobre los estados intersexuales.

12 R. Huertas y E. Novella, "Sexo y modernidad en la España de la Segunda República. Los discursos de la ciencia", Arbor Ciencia, Pensamiento y Cultura, 764, (2013), p. 2.

13 A. Aguado, "Entre lo público y lo privado: sufragio y divorcio en la Segunda República", Ayer, 60, (2005), p. 107.

14 J. Daza, "La ley de divorcio de 1932. Presupuestos ideológicos y significación política", Alternativas. Cuadernos de Trabajo Social, 1, (1992), p. 163-175.

15 J. M. Garat, "En Cataluña existe ya el aborto legal", Mundo Gráfico, 1332, (1937), p. 5-6; J. Sobreques i Callico, "Cataluña tuvo durante la República la ley del aborto más progresista de Europa" El País (13- II-1983).

16 Sobre el control del cuerpo femenino como manifestación de las relaciones de poder entre hombres y mujeres durante el primer tercio del siglo XX véase, M. Llona, "Los otros cuerpos disciplinados. Relaciones de género y estrategias de autocontrol del cuerpo femenino (primer tercio del siglo XX)", ARENAL, 14, (2007), pp. 79-108.

17 E. Amezúa, "La línea política de la reforma sexual. Memoria histórica y planes de futuro", Anuario de Sexología, 8, (2004), p. 158.

18 F. Vázquez y A. Moreno, Sexo y Razón. Una genealogía de la moral sexual en España (XVI-XX), Madrid, Akal, 1997, p. 136.

19 E. Noguera y L. Huerta (coord.), Libro de las Primeras Jornadas Eugenésicas Españolas: Programa. Ponencias. Genética, eugenesia y pedagogía sexual, Madrid, Javier Morata, 1934; M. Nash, "Aproximación al movimiento eugénico español: el Primer Curso Eugénico Español y la aportación del Dr. Sebastian Recassens", Gimbernat, Revista Catalana d'Història de la Medicina i de la Ciencia, 4, (1985).

20 M. A. Barrachine, "Maternidad, feminidad, sexualidad. Algunos aspectos de las Primeras Jornadas Eugénicas Españolas (Madrid, 1928-Madrid, 1933)", Hispania, 218, (2004), pp. 1003-1026.

21 G. Marañón, Tres ensayos sobre la vida sexual, Madrid, Biblioteca Nueva, 1926.

22 R. Castejón, "Marañón y la identidad sexual: biología, sexualidad y género en la España de la década de 1920", Arbor Ciencia, Pensamiento y Cultura, 759, (2003). 
Sería, empero, una mujer que no llegó a cumplir los veinte años, la que nos legó los textos más vanguardistas de la época: Hildegart Rodríguez ${ }^{23}$. La importancia sociológica y política de la joven quedó sin embargo relegada por la prensa sensacionalista a la luz de los tristes acontecimientos que terminaron con su vida. La prematura muerte de Hildegart a manos de su propia madre fue un suceso que conmocionó a la sociedad española y que yuguló la espectacular trayectoria de una joven prodigio contribuyendo a que sus éxitos intelectuales palidecieran ante el macabro crimen parricida ${ }^{24}$. En su trayectoria — tan fugaz como abrumadora ${ }^{25}$ - defendió medidas a favor del abolicionismo y la despenalización del adulterio; divulgó, además, ideas eugenésicas y neomaltusianas, promoviendo una procreación consciente y un nuevo tipo de relaciones amorosas y sexuales alejadas de la ortodoxia moral imperante. En definitiva, su discurso pretendía despojar a la sexualidad de influencias represivas y sexistas, siendo una activa defensora de la instrucción sexual desde la escuela ${ }^{26}$.

Pese al esfuerzo y la preocupación pedagógica ${ }^{27}$ no se pudo incluir en las escuelas la asignatura de educación sexual ${ }^{28}$; con todo, la sexualidad fue un fértil terreno de estudio donde confluyó el interés de posturas freudianas ${ }^{29}$, eugenésicas y anarquistas ${ }^{30}$, que a veces de manera conjunta y otras separadas, contribuyeron a la "marcha triunfal del sexo". El auge editorial de publicaciones científico-pedagógicas sobre sexología puso de manifiesto tanto la necesidad de replantear a nivel discursivo la sexualidad humana, como la demanda de una población que reclamaba conocer y aprender sobre sexo. En este sentido, surgió un importante número de publicaciones divulgativas entre las que destacan las siguientes colecciones ${ }^{31}$ : La pequeña enciclopedia de educación sexual (1932), La biblioteca de educación sexual de Antonio de Velilla (1932-1933), Temas sexuales. Biblioteca de divulgación sexual, Ángel M. de Lucenay (1932-1937) y Cultura sexual (1936-1937). La abrumadora cantidad de este tipo de publicaciones - solo la colección de Lucenay contaba con sesenta volúmenes - constituyó un aporte fundamental a la hora de "extraer la sexualidad del claustrofóbico recinto del confesionario" ${ }^{32}$ y acercarlo a una población marcada por la desinformación.

23 Véase, L. Vicente, "Republicanismo, Anarquismo y Revolución Sexual: El magma de ideas en que nació Hildegart Rodríguez", Libre pensamiento, 82, (2015), pp. 52-59.

24 J. Rámila, "Hildegart Rodríguez: La historia que conmocionó a la II República Española" Quadernos de criminología, 18, (2012), pp. 8-19.

25 Algunos de sus títulos más importantes en lo referente a sexualidad fueron: El problema eugénico. Punto de vista de una mujer moderna, Madrid, Gráfica Socialista, 1930; La limitación de la prole: un deber del proletariado consciente, Madrid, Gráfica Socialista, 1930; Sexo y amor; La revolución sexual, Valencia, Cuadernos de Cultura 41, 1931; El problema sexual tratado por una mujer española, Madrid, Javier Morata, 1931; Educación sexual, Madrid, Gráfica Socialista, Madrid 1931; Malthusismo y Neomalthusismo. El control de la natalidad, Madrid, Javier Morata, 1932.

26 R. Huertas y E. Novella, "Sexo y modernidad...".

27 C. Diego, "La educación sexual en la escuela primaria: intento frustrado de los eugenistas", Cuestiones de género: de la igualdad y la diferencia, 9, (2014), pp. 158-181.

28 J. B. Seoane, "Escuela, higiene y sexualidad infantil" en, J. Mainer, Pensar críticamente la educación escolar: perspectivas y controversias, Zaragoza, Universidad de Zaragoza, 2008, p. 247.

29 M. del Cura González y R Huertas García-Alejo, "Medicina y sexualidad infantil en la España de los años treinta. La aportación del psicoanálisis a la pedagogía sexual", Hispania, 218, (2004), pp. 987-100.

30 R. Cleminson, Anarquismo y sexualidad en España, 1900-1939, Universidad de Cádiz, Cádiz, 2008; E. Masjuan, La ecología humana en el anarquismo ibérico: urbanismo «orgánico» o ecológico, neomaltusianismo y naturismo social, Barcelona, Icaria, 2000; F. J. Navarro, El paraíso de la razón. La revista Estudios 19281937 y el mundo cultural anarquista, Valencia, Institución Alfonso el Magnánimo, 1997.

31 J. L. Guereña, Detrás de la cortina..., pp. 92-103.

32 M. Zubiarre, Culturas del erotismo..., p. 81. 
La literatura de divulgación sexual no cesó una vez terminada la Guerra Civil aunque dio otro giro en cuanto a su contenido y sus bases morales. Si la eugenesia se había utilizado durante la Segunda República desde los preceptos más modernos defendidos por Francis Galton, durante el franquismo se utilizó como instrumento represor del bando republicano ${ }^{33}$. El principal referente a ese respecto lo encontramos en la figura de Antonio Vallejo Nájera, que supo promocionar una personal visión de la eugenesia al reconciliar las doctrinas alemanas de la higiene racial con los preceptos de la moral católica ${ }^{34}$. Junto a López Ibor ${ }^{35}$, las aportaciones de Vallejo Nájera sobre sexualidad serían las que detentarían el pensamiento hegemónico durante el régimen, recuperando la tradicional asociación entre sexualidad y reproducción, condenando $-\mathrm{y}$ criminalizando ${ }^{36}$ - la homosexualidad y negando el instinto sexual femenino ${ }^{37}$. La modernidad sexual a la que se había aspirado durante la República se disipó dentro de este desolador panorama, en el que solo la obra de Serrano Vicens ${ }^{38}$ figura como notable excepción.

En cualquier caso, la instauración de un régimen democrático en 1931 marcó el inicio de un periodo de profundas reformas políticas que se extendieron al terreno social, dando paso a un periodo en la historia de la sexualidad española que incluye los avances teóricos desde la medicina, la psiquiatría o la pedagogía y también, la representación explícita del sexo como medio de excitación ${ }^{39}$. Al igual que el resto de Europa, la España del primer tercio del siglo XX escribe copiosamente sobre sexo y acompaña la letra impresa con una rica iconografía visual y artística ${ }^{40}$. El nacimiento de la noción "pornografía" es un invento moderno y occidental cuya expansión, como veremos a continuación, está íntimamente vinculada a al desarrollo de la fotografía.

\section{NACIMIENTO Y DESARROLLO DE LA NOCIÓN PORNOGRAFÍA}

Las representaciones sexuales explícitas han estado presentes en todos los periodos históricos ${ }^{41}$. Desde la Venus de Willendorf hasta las propuestas más avangarde del posporno con Annie Sprinkle, el recorrido histórico de este tipo de cuestiones se atisba

33 A. Vallejo-Nájera, Eugenesia de la Hispanidad y Regeneración de la Raza, Burgos, Editorial Española, 1937, p. 132.

34 J. Bandrés, E. Zubieta, R. Llavona, "Mujeres extraviadas: psicología y prostitución en la España de posguerra", Universitas Psychologica, 13, (2014), p. 1.670.

35 A. González, "Sobre los orígenes de la psiquiatría franquista: la psicopatología de guerra de J. J. López Ibor" en F. González (coord.), Ciencia y técnica entre la paz y la guerra: 1714, 1814, 1914, (2016), p. 563-569.

36 A este respecto véase: V. Mora, Al margen de la naturaleza. La persecución de la homosexualidad durante el franquismo, Madrid, Debate, 2016.

37 "En las mujeres tiene insignificante importancia el impulso interno, siendo fácil a la mujer permanecer virgen de cuerpo y de espíritu durante mucho tiempo, si las influencias externas no quebrantan la virginidad" en, A. Vallejo-Nájera, Eugenesia de la Hispanidad..., p. 132.

38 J. Monferrer, "Serrano Vicens: el Kinsey español", en R. Osborne, Mujeres bajo sospecha: memoria y sexualidad (1930-1980), Madrid, Fundamentos, 2012, pp. 218-232.

39 España contaba con una importante tradición de este tipo de representaciones donde la obra atribuida a los hermanos Bécquer, Los borbones en pelota, figura como máximo exponente; véase I. Burdiel, Los borbones en pelota, Institución Fernando el Católico, 2012.

40 M. Zubiarre, Culturas del erotismo..., p. 127.

41 "Para la historia de la imagen X gráfica, Walter Kendrick propone tres eras para apreciar la imagen explícita de la sexualidad. La era Pre Pornográfica que abarca las representaciones dadas desde el origen de la civilización hasta la era Victoriana, la era Pornográfica donde se acuña la palabra pornografía y la era Post Pornográfica que se da finalizando la década del 60 hasta nuestros días", en D. Romero, "XXX Pensar la pornografía", El Artista, 6, (2009), p. 104. 
inabarcable. Ahora bien, la pregunta se nos antoja obligada, ¿se deben considerar todas estas representaciones como pornográficas? La respuesta, sin duda, no puede contestarse desde una posición simple o absoluta y quedará indiscutiblemente condicionada por el contexto histórico y las éticas morales de cada periodo. La categorización de lo pornográfico ha generado enormes problemas al intentar si quiera aproximarse a una definición unívoca y concreta, tanto que todavía hoy es difícil adentrarse en sus intrincados vaivenes conceptuales y desligarla de otras expresiones. De hecho, los términos pornografía, erotismo y arte aparecen generalmente diluidos en un mismo espacio, separados por límites tan débiles como imaginarios, especialmente a finales del siglo XIX, cuando los primeros daguerrotipos franceses mostraban formas y encuadres prestados de la pintura. Así comienzan a desfilar por los gabinetes fotográficos salomés, cleopatras, majas, odaliscas y virginales afroditas ${ }^{42}$.

Al mismo tiempo, El origen del mundo de Coubert, El pecado de Henrich Lossow o, más recientemente, La lección de guitarra de Balthus, son buenos ejemplos de que arte, pornografía y erotismo son términos intercambiables, de modo que la pornografía puede ser artística o el arte puede representar escenas pornográficas. Asumiendo como evidente esta afirmación, el debate más intenso se ubica en la distinción entre lo erótico y lo pornográfico. La línea divisoria que separa ambas expresiones ha constituido siempre un tamiz poroso, una frontera constantemente cambiante, donde la primera marca el límite cultural de lo permitido sexualmente, mientras que la otra representa la cara oscura de esa misma realidad, conformando una dualidad tan simple como maniquea. El concepto erótico implicaría así una estética artística de lo sexual; al tiempo que la pornografía quedaría ligada a una naturaleza negativa cuyo estigma se ubica siempre en un plano subjetivo. De esta forma, la relación de la pornografía con la obscenidad responde al hecho de que la primera representa todo aquello que no encaja en las normas, valores y creencias que trata de imponer el paradigma sexual tradicional ${ }^{43}$. La mayor parte de los estudios sobre pornografía coinciden en situar el nacimiento de esta connotación peyorativa a finales del siglo XIX cuando, gracias al perfeccionamiento de algunas técnicas de reproducción gráficas, las capas más pobres de la población tuvieron acceso a este tipo de material. Pero, sin duda, fue la fotografía la que funcionó como verdadero catalizador de su circulación masiva, contribuyendo a la definitiva democratización de las imágenes de contenido sexual entre todos los estratos sociales. En el momento en que las élites dejan de tener un acceso exclusivo $^{44}$ a las representaciones sexuales explícitas, este tipo de publicaciones son condenadas porque se asume en ellas un carácter potencialmente subversivo, vinculado a los bajos fondos, al delito e incluso a lo patológico; rasgos con los que todavía hoy estaría estrechamente vinculada.

Así pues, la expansión y condena de las imágenes pornográficas discurrieron por caminos paralelos. Las representaciones sexuales explícitas se vieron condicionadas por códigos religiosos, morales $\mathrm{y}$, desde aquel momento, también legislativos ${ }^{45}$, quedando

42 C. Figari, "Placeres a la carta: consumo de pornografía y constitución de géneros", La ventana. Revista de estudios de género, 3, (2008), p.179.

43 M. Rodríguez, Prácticas postporno en el Estado español..., p. 34.

44 Un buen ejemplo es el museo secreto de Nápoles abierto en 1817. Como recuerda Preciado "Según decreto real, sólo los hombres aristócratas -ni las mujeres ni los niños, ni las clases populares- podían acceder a ese espacio. El Museo Secreto opera una segregación política de la mirada en términos de género, de clase y de edad", en P. B. Preciado, "Museo, basura urbana y pornografía", Zehar: revista de Arteleku-ko aldizkaria, 64, (2008), p. 40.

45 “... es verosímil que sólo a partir del XIX estas representaciones hayan comenzado a ser juzgadas como 
desplazadas al terreno delictivo. Entonces, ¿cómo se explica la enorme difusión que alcanzaron precisamente en este momento las representaciones sexuales? Como apunta Foucault, "si bien es cierto que se pregunta, se vigila y se acecha la sexualidad, del otro lado, se generan estrategias para escapar de ese poder, para engañarlo, para disfrazarlo"46. Una de las principales estrategias para evadir la censura durante el siglo XIX fue manifestar que dicha representación contenía "otra cosa" y que no se trataba "únicamente de sexo"47. Así pues, a finales del siglo XIX se distinguen tres grupos de fotografías de cuerpos desnudos: en primer lugar la fotografía médica de corte antropológico, que surgió como un inesperado cómplice en la circulación de este tipo de material (Figura 1); tanto que es imposible disociar la historia de las primeras representaciones pornográficas de la historia de la fotografía médica y la fotografía colonial ${ }^{48}$. De otro lado la fotografía erótica, con encuadres y posturas inspirados en el mundo pictórico, logró camuflarse en la visión artística de la desnudez al asumir que "solo puede ser considerada obscena en virtud de un alarde imaginativo"49 (Figura 2). Por último, diferenciamos las representaciones pornográficas propiamente dichas que fueron una realidad persistentemente oculta y su tráfico se restringiría únicamente a la clandestinidad, desarrollándose todo un mercado negro a su alrededor (Figura 3).

Figura 1. Fotografía antropológica

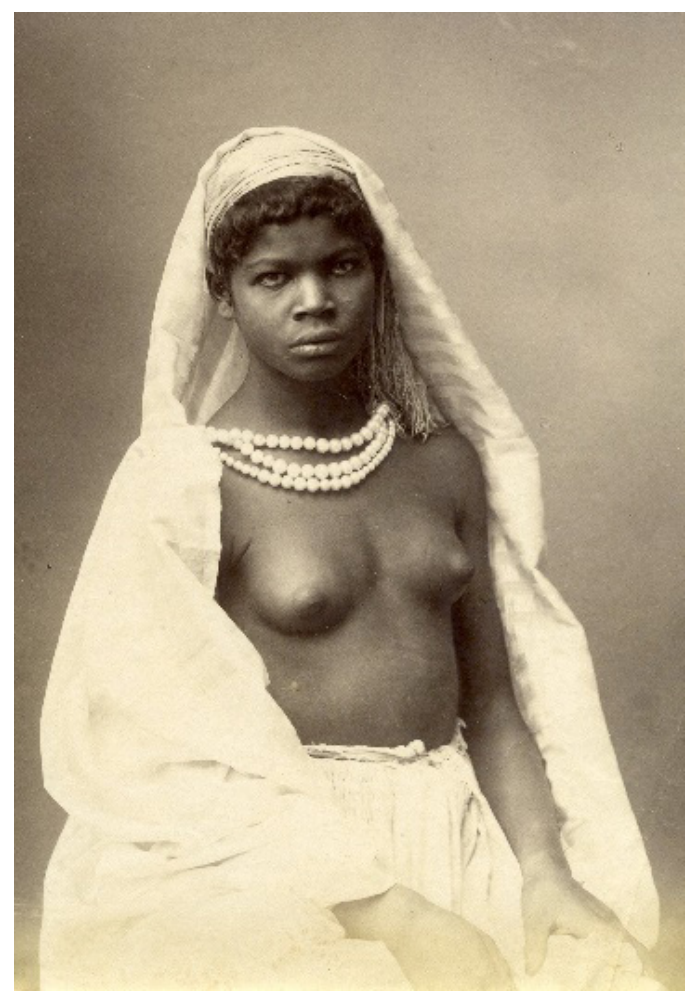

Fuente: Fondo fotográfico Carmen Guillén

licenciosas o inmorales. En EE.UU la primera ley antiobscenidad viene de 1842 y en Gran Bretaña de 1868", en J. Guimón, "Pornografía y...", p. 5.

46 M. Foucault, Historia de la sexualidad..., p. 47.

47 B. Arcand: El jaguar y el oso hormiguero..., p. 31.

48 P. B. Preciado, "Museo, basura urbana y...", p.46.

49 M. Lucenay, La pornografía, Madrid, Editorial Fénix, 1933, p. 32. 
Figura 2. Fotografía erótica

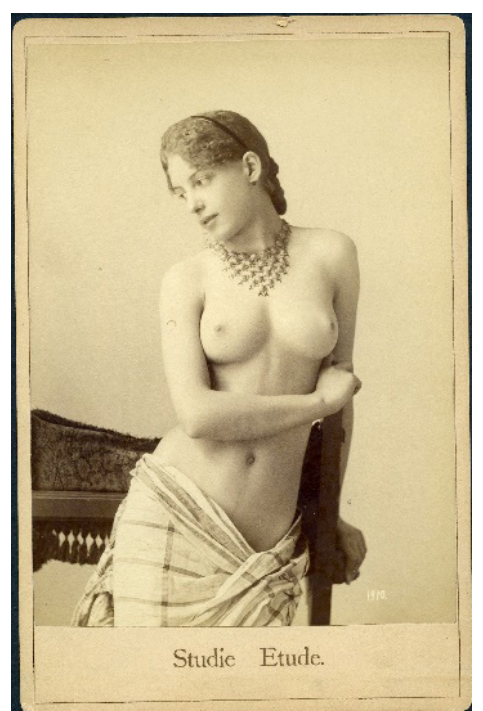

Fuente: Fondo fotográfico Carmen Guillén

Figura 3. Fotografía pornográfica

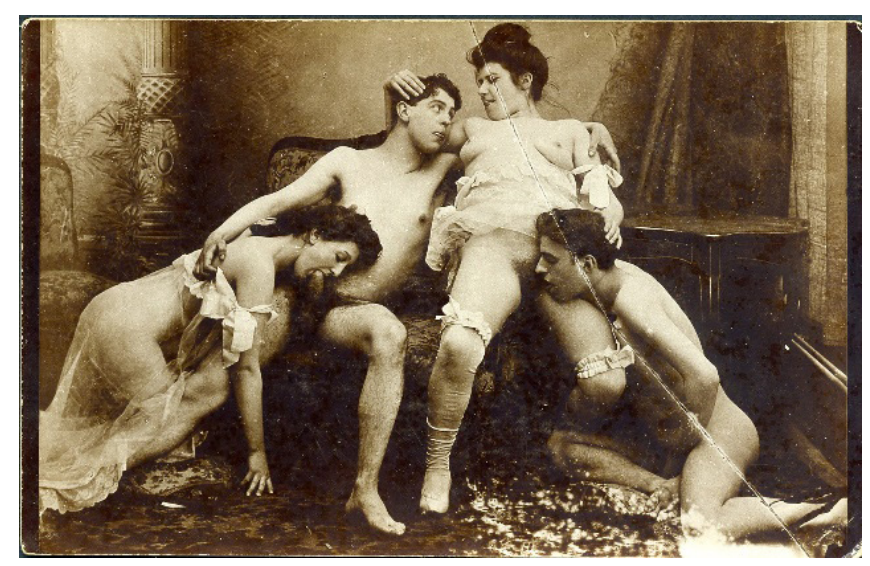

Fuente: Fondo fotográfico Carmen Guillén

Las representaciones sexuales se camuflaron así entre la clandestinidad, el arte y la ciencia médica en busca de nuevas formas de legitimidad. En este contexto surge toda una regulación en nombre del beneficio social que intenta clasificar los límites de lo permitido sexualmente. En palabras de María Rodríguez, el cuerpo desnudo se convierte entonces en una categoría capaz de dictaminar qué es lo púdico y lo impúdico, lo correcto y lo incorrecto, lo normal y lo patológico, lo moral y lo inmoral ${ }^{50}$; de modo que el nacimiento y conceptualización de la noción pornografía constituye un complicado recorrido en el que confluyen parámetros sociales, legislativos y morales. Más allá de estas cuestiones, todavía hoy se sitúa como uno de los debates más controvertidos, dentro y fuera del feminismo, entre quienes la critican por su vinculación a la explotación del cuerpo de la mujer y quienes la defienden como una modalidad de libertad sexual y como un instrumento capaz de transformar las condiciones opresivas de la mujer ${ }^{51}$.

50 M. Rodríguez, Prácticas postporno en el Estado español..., p. 31.

51 Véase, A. León, “¿Disidencia dentro del feminismo?”, Revista Internacional de Sociología, 3, (2009), p. 


\section{PORNOGRAFÍA Y EROTISMO EN LA ESPAÑA REPUBLICANA}

A la tradicional visión de las dos Españas políticas habría que añadir otra división igual de cierta pero menos conocida: la de una España anclada en la tradición moral católica y casta, contrapuesta a otra libidinosa y descocada que se manifestó a través de un importante número de representaciones sicalípticas ${ }^{52}$. Muy influenciada por la cultura foránea —especialmente la francesa - la pornografía en la España de la época fue más que diversa: desde la literatura erótica en el marco de la "ola verde"53, hasta las primeras representaciones sexuales en el cinematógrafo, pasando por el vodevil y el cuplé en teatros, sin olvidar el floreciente mercado de la postal erótica; la oferta pornográfica española constituía una realidad incuestionable. No era éste un asunto nuevo, "la bestia de la sensualidad" ya venía "envenenando la vida de las generaciones futuras" desde finales del siglo XIX y para las primeras décadas del XX se revelaba como un verdadero problema social. Así lo denunció en 1927 la Liga contra la pública inmoralidad de Valencia, donde la cifra de libros, novelas, revistas y folletos pornográficos ascendía a "millones de ejemplares" 54 . El asunto no se circunscribía a la ciudad levantina sino que "se puede observar en todas las capitales españolas, porque a todas llega el mal con mayor o menor intensidad, sin encarecer lo que ocurre en Madrid, donde hasta el aire está envenenado de la corrupción sensualista"55.

La narrativa sicalíptica contaba pues con una importante herencia ${ }^{56}$ y para el primer tercio del siglo XX había alcanzado ya una notable fama como parte de la cultura popular española. Frente a una tradición que Amezúa califica como "erotismo blando"57, a partir los años treinta obtienen mayor éxito obras de argumentos más obscenos. Con Madrid y Barcelona como epicentros nacionales de distribución, durante el periodo republicano resalta el nombre propio - y todavía poco conocido ${ }^{58}$ - de Antonio Astiazarain que, desde su editorial de Francia, tradujo y editó alguna de las obras más vendidas de la época. Su contenido irreverente y sin trampas eufemísticas en el título, incluía obras de descarado anticlericalismo, incesto e incluso zoofilia ${ }^{59}$. Los títulos más provocadores, y también los de mayor tirada durante aquellos años, lo hicieron bajo el sello de este enigmático personaje: Manual del perfecto jodedor, A mi tutor le gustan muy putas o A la caza de coño ${ }^{60}$.

Se trataba de colecciones periódicas, normalmente mensuales, vendidas en formato de libro de bolsillo a un precio asequible que solían estar disponibles en quioscos y puestos

\section{9-588.}

52 M. Zubiarre, Culturas del erotismo...

53 "Avalancha de publicaciones con carácter erótico, pícaro, libertino, o sicalíptico, que había ido creciendo de manera escandalosa (...) hasta la orden de persecución de las mismas por parte del gobierno de la dictadura de Primo de Rivera", en E. Amezúa, Los hijos de don Santiago..., p. 89.

54 "Salvemos la juventud", en Avalancha, La, Pamplona (24- IV-1927), 770, p. 1.

55 Ibídem, p. 2.

56 L. Litvak, Antología de la novela corta erótica española de entreguerras, 1918-1936, Madrid, Taurus, 1994.

57 E. Amezúa, Los hijos de don Santiago..., p.30. A este respecto véase la obra de reciente publicación sobre la biografía de Sanxo Farrerons, editor de novelas eróticas a principios del siglo XX: J. L. Guereña, El sardinista pornógrafo, Ed. Renacimiento, 2019.

58 “...no sabemos prácticamente nada de este personaje” en J. L. Guereña, Detrás de la cortina..., p. 466 y SS.

59 J. Blas, "La novela corta erótica española: noticia bibliográfica", en Los territorios literarios de la historia del placer: I Coloquio de Erótica Hispana, (1996), p. 17.

60 J. L. Guereña, Detrás de la cortina..., "Apéndice publicaciones Antonio Astiazarain: cronología comparada (1933-1934)", pp. 476-478. 
callejeros $^{61}$. Su atractivo residía en un contenido literario sórdido rematado por llamativas portadas con imágenes explícitas ${ }^{62}$ e interiores ilustrados atrevidamente que, en ocasiones, incluían fotografías ${ }^{63}$. La cuantiosa oferta de este tipo de publicaciones contrasta con una legislación ${ }^{64}$ represiva y censora; en consecuencia, no faltaron las multas ejemplarizantes ${ }^{65}$ y, sobre todo, los alegatos desde los sectores más moralistas contra la distribución y venta de estas publicaciones:

En los tiempos de la Dictadura se persiguió ferozmente a la pornografía, que no por eso dejó de existir, pero se efectuaba de una manera clandestina y desde luego de una manera muy inasequible a la juventud. Hoy época de libertad, no se pone cortapisa a nada y la pornografía ya se exhibe de una forma descocada y escandalosa. [Se ven en las calles] puestos de libros al aire libre con portadas indecentes de hombres y mujeres enseñando todo lo que Dios le dio en posturas lascivas y con puercos titulares ${ }^{66}$.

No obstante, como la privación es causa de apetito, el control y censura de la pornografía no disminuyó su mercado, más bien potenció las estrategias de distribución bajo el paraguas de la insinuación y el arte. De hecho, el mercado sicalíptico no se limitó a las novelas eróticas, sino que contaba con una considerable y heterogénea oferta. Son bastantes, por ejemplo, las revistas de carácter frívolo que incluyeron entre sus contenidos abundantes desnudos fotográficos dentro de la sección "páginas artísticas". Las revistas alcanzaron entonces un papel cultural preponderante dentro del proceso modernizador que vivía España. La relajación o desaparición de ciertas restricciones generó nuevas formas de ocio en un contexto de marcado progreso cultural y social. En los años treinta, con el auge en toda Europa de lo que se conoció entonces como "desnudismo", comenzaron a publicarse en España diversas revistas que fomentaban un estilo de vida naturista a través de recetas vegetarianas, remedios médicos alternativos y promoción de los beneficios del cuerpo desnudo. De modo que Gimnos, Helios, Biofilia, Macrocosmo y, principalmente Pentalfa ${ }^{67}$, contribuyeron con sus portadas e imágenes interiores a preconizar el desnudo como forma de vida saludable. Pese a que estas publicaciones no respondían a una finalidad sexual, formaron parte del espectro erótico de la época al contribuir, como no lo hizo otro medio, a la exhibición del cuerpo masculino.

De esta forma el consumo de los desnudos ahora se considerará propio del arte y de la modernidad, lo que justificaba su amplia difusión en las revistas ilustradas de la época. Si bien ya existían precedentes de publicaciones puramente eróticas ${ }^{68}$, la principal diferencia respecto al contenido estribó en el predominio de la fotografía sobre el dibujo, coincidiendo con el final de la dictadura primoriverista. Fueron muchas las revistas que abordaron la temática sicalíptica, entre las que destacan durante el periodo republicano: Muchas Gracias, Tararí, Crónica, y La Gaceta Galante (Figura 4). Todas ellas ofrecían un contenido similar

61 M. Zubiarre, Culturas del erotismo..., p. 340.

62 "La colección afrodita contaba con una portada con 'una fotografía pornográfica' salvo el número 11 en el cual se trataba de un dibujo" en, J. L. Guereña, Detrás de la cortina..., p. 475.

63 Concretamente el Manual del perfecto jodedor incluía una rica colección fotográfica.

64 "En 12 de septiembre de 1924 cuarenta naciones, y entre ellas España, firmaron en Ginebra el convenio para la represión de la pornografía", Gaceta de Madrid, 9, 09-I-1925, p. 100.

65 "D. Luis Pérez López, domiciliado en la calle de Baltasar Bachero, número 8, [se le impone] la multa de 30 pesetas, por venta de novelas pornográfica" en Gaceta de Madrid, 62, 2-III-1936, p. 1798.

66 "La pornografía en las calles", en La Verdad de Murcia (3-VIII-1932), p. 1.

67 C. Cubero, La pérdida del pudor: el naturismo libertario español (1900-1936), Madrid, LaMalatesta, 2015.

68 J. Soldelvilla, Psicalíptics. Erotisme i trangressió a les revistes ilustrades del principi del segle XX, Barcelona, Museu d'Art de Sabadell. 
que incluía un buen número de chistes ilustrados, fotografías de desnudos femeninos, textos breves de carácter erótico-satírico y gran cantidad de publicidad referida a artículos de índole sexual — desde productos de higiene íntima de la mujer hasta preservativos "completamente irrompibles", con especial incidencia en fármacos que prometían solucionar los problemas de "astenia genital" masculina-. En todas se advierte la influencia de los modelos más vanguardistas de edición de magazine franceses, con un importante número de fotografías y escuetos pies de fotos que, no solo venían firmadas por destacados fotógrafos españoles como Mendoza o Federico Ribas, sino también por reconocidos profesionales internacionales como el vienés Manasse que participaba asiduamente en Crónica.

Figura 4. Interior de la Gaceta Galante (1932)

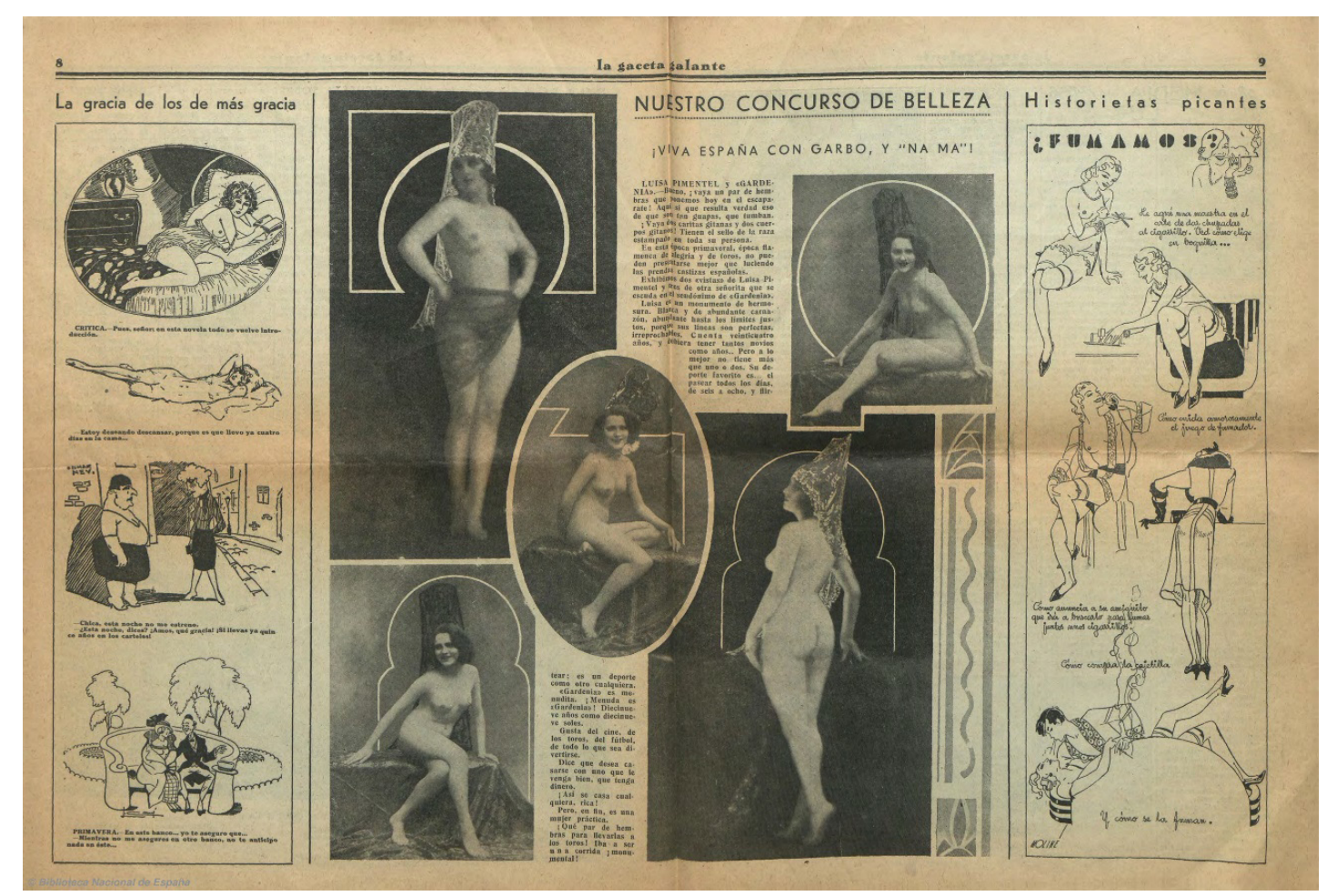

Fuente: Gaceta Galante (1932). Imágenes propiedad de la Biblioteca Nacional de España

Los desnudos femeninos correspondían muchas veces a populares artistas de la época, sobre todo en la revista Tararí, especializada en la información sobre varietés, teatro, cabaret, canción española y espectáculos en general. Para entonces, el destape —al menos el femenino- había traspasado el papel couché para subir a las tablas de los escenarios donde las obras de contenido licencioso empezaban a cobrar un importante éxito. La pipa de oro, donde aparecían por vez primera "cinco senos desnudos" fue calificada por la revista Crónica (Figura 5) como un suceso, "mucho más importante que la discusión del Estatuto de Cataluña" y recogido en un artículo que por su elocuencia merece ser trascrito:

Los diez senos en libertad de estas cinco muchachitas (...) son diez senos desafiando valientemente todo un pasado lleno de tradiciones y de triples enaguas; son diez puntitas breves pinchando en la panza hueca de una moral convencional, y son diez senos en lucha abierta contra la hipocresía, contra los sostenes y contra la belleza con truco. Son también diez senos como diez banderas de 1932 y como diez altavoces de la civilización real y republicana de la España de hoy ${ }^{69}$.

69 Revista Crónica (15-V-1932), 131, pp. 6-7. 
Figura 5. Noticia del estreno de "La pipa de oro"

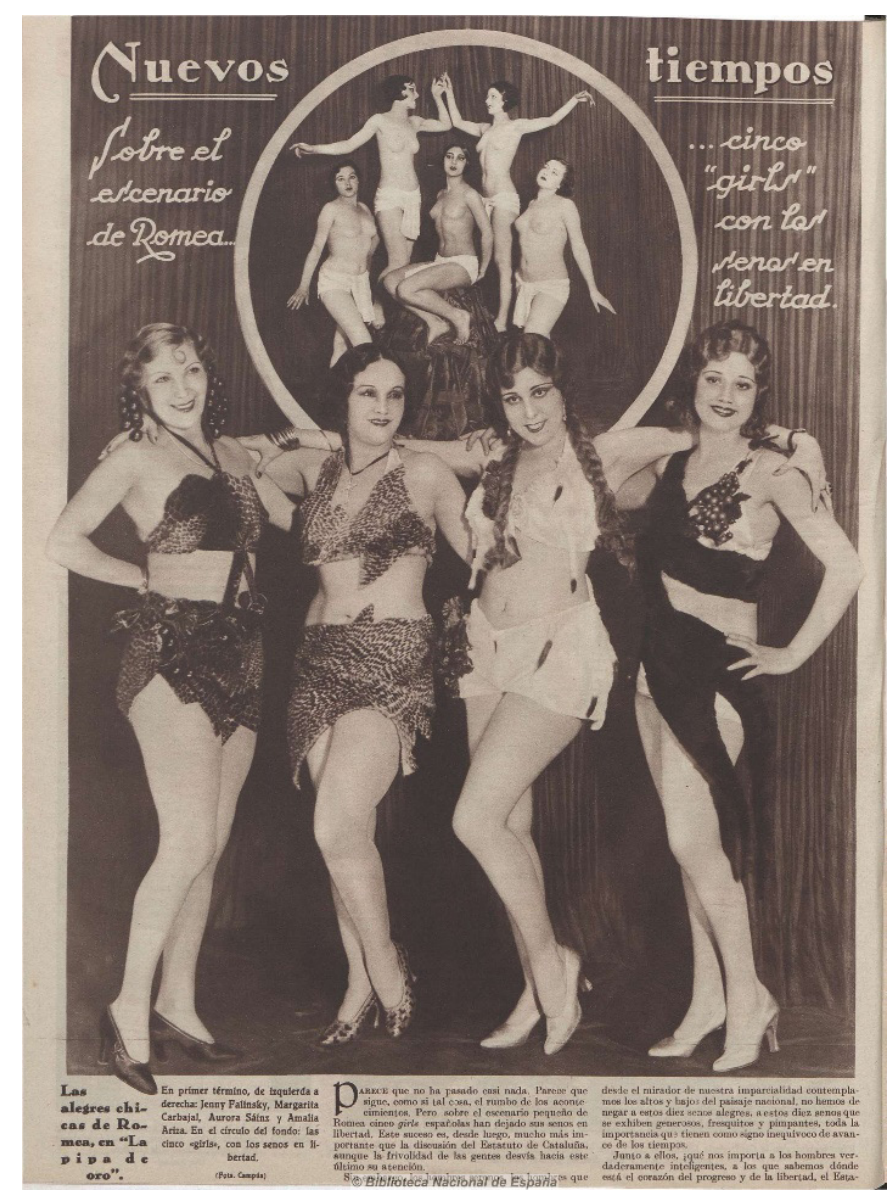

Fuente: Revista Crónica (1932) Imágenes propiedad de la Biblioteca Nacional de España

Mientras en el terreno político la República otorgó nuevos derechos cívicos y jurídicos a las mujeres, la emancipación femenina se tradujo dentro de los escenarios en una liberación de sus cuerpos que se convirtieron en el principal aliciente de los espectáculos ${ }^{70}$. Al fin y al cabo, el exceso de frivolidad sobre las tablas no deja de ser una respuesta social reaccionaria a la represión y censura moral de aquellos años, que la República atenuó, pero solo en parte. De hecho, en las letras de estos cuplés abundan las metáforas y los dobles sentidos como retóricas lingüísticas capaces de enmascarar la obscenidad del contenido; se muestra el sexo, pero no se menciona expresamente:

Aquí te ofrezco el higo/La fruta más sabrosa/ La más estimulante,

La más apetitosa/ La fruta que a los hombres/ Les gusta con pasión

Por el higo mucho de ellos /Se han quedado sin un botón/ El higo que te ofrezco yo

Es fresco, dulce y chiquitín/ Cuando lo pruebes ya verás/ Como vendrás a repetir

Al higuí, al higuíl Con la mano no/ Con la boca sí ${ }^{11}$.

70 E. Ricci, "La ola verde en la prensa y en los espectáculos en la II República", en J. M. Desvois (coord.), Prensa, impresos, lectura en el mundo hispánico contemporáneo, Université Michel de Montaigne Bordeaux, 2005, p. 310.

71 Fragmento de uno de los cuplés de la revista musical La pipa de oro de Enrique Parada y Joaquín Jiménez en, Guión. Revista de espectáculos (mayo de 1932), número 6. 
Las actuaciones picarescas compitieron como entretenimientos populares con el inicio y expansión del cine sonoro, tanto nacional como internacional. El principio de libertad de expresión defendido en el artículo 34 de la constitución republicana no fue aplicado al cine, donde se desarrolló un aparato censor que, si bien centró sus esfuerzos en cuestiones políticas $^{72}$, estableció también limitaciones de tipo moral. Se evitó que aparecieran en pantalla relaciones extramatrimoniales, violaciones, desnudos y escenas de aproximación sexual, incluso si se trataba de animales. Un total de quince películas sufrieron recortes de metraje por este tipo de cuestiones, como sucediera en la cinta En el país de la miel (1936), de donde fue suprimida la escena de la cópula de las abejas; mientras que solo dos —Adúltera (1935) y La mujer desnuda (1935) — fueron prohibidas en todo el territorio nacional ${ }^{73}$. Pese a estos controles, el gobierno republicano no consiguió contener la inevitable llegada al celuloide de las primeras películas pornográficas ${ }^{74}$. Se trataba de funciones privadas, 0 de muy costoso acceso ${ }^{75}$, enfocadas a un mercado esencialmente masculino como así lo atestiguan los habituales sobrenombres con los que se conocían este tipo de pases, "sesión para solteros" o "no apto para señoritas"76. Incluso en ocasiones se realizaban fuera de las salas de cine, en las conocidas casas de lenocinio o mueblés ${ }^{77}$, que para aquel momento ya constituían importantes espacios de sociabilidad masculina ${ }^{78}$. Estos espectáculos se situaron preferentemente en Barcelona, Madrid, Valencia y Málaga ${ }^{79}$ y, según Lucenay, se desarrollaban "con una antinaturalidad asombrosa en la que no se omitía detalle, por obsceno y pernicioso que fuera" 80 :

Ha llegado a nuestro conocimiento que en el Cinema Puerta se dio anoche una función para hombres solos, luego de la ordinaria (...) en la que se rodó una película de lo más inmoral y obscena. Sabemos que hubo bastante gente y varios menores de edad. Este desvergonzado comercio de la pornografía se repetirá esta noche por su feliz resultado económico ${ }^{81}$.

Más allá del cine, el teatro o la literatura, si la pornografía tuvo un medio de difusión por excelencia durante la República, ese fue la postal, que consiguió transformar el sexo en un

72 "La censura fue radicalmente anticomunista. Ni Octubre, ni El acorazado Potemkin se pudieron proyectar legalmente, ni en público, ni en privado a cargo de una agrupación." en, M. Paz y J. Montero, "Las películas censuradas durante la Segunda República. Valores y temores de la sociedad republicana española (19311936)", Estudios sobre el Mensaje Periodístico, 369, (2010), p. 369.

73 Ibídem, p. 386.

74 Los inicios del cine erótico español se remontan a los años veinte y están estrechamente vinculados a la figura de Alfonso XIII. Recientemente la Generalidad Valenciana ha restaurado tres cortometrajes de la colección del monarca encargados por el conde de Romanones a los hermanos Baños, cuyos títulos son: El confesor, El ministro y Consultorio de señoras. Véase, J. Roglan, La Barcelona erótica, Barcelona, Angle, 2003, p. 130.

75 Ocasionalmente se debía pronunciar una contraseña para tener acceso a la sesión: "Al entrar en el local abonaron el importe de la localidad, pronunciando la consigna que debía franquearles la entrada, y que era: 'Pellicer 32'”, en "Cine pornográfico", en La Vanguardia (22-V-1932), p. 7.

76 "Eroticón, film checo de vanguardia no apto para señorita, primera película checa y una de las primeras del mundo del cine erótico", en ABC Madrid (14-II-1932), p. 52.

77 "La policía tuvo noticias de que en un «meublé» de la calle de Lérida se proyectaban películas pornográficas, cobrándose tres pesetas por espectador para poder asistir a la proyección" en "Cine pornográfico", en La Vanguardia (22-V-1932), p. 7.

78 J. L. Guereña, "El burdel como espacio de sociabilidad", Hispania, 214, (2003), p. 551-570.

79 M. Lucenay, La pornografía..., p. 68 y ss.

80 Ibídem, p. 68.

81 La Verdad de Murcia (1-V-1932), p. 7. 
producto de consumo portátil. La mayor parte de los desnudos fotográficos que circularon por España en los inicios del siglo XX fueron obra de especialistas europeos, cuyas fotografías se vendían como postales en quioscos y soportales ${ }^{82}$. En España resultaba difícil encontrar modelos para este tipo de imágenes pues, según Lucenay "ni las prostitutas se avienen a las ofertas más beneficiosas, a no ser con el rostro cubierto"83. Por lo general, las fotografías se obtenían de manera que, mediante el retoque, se sustituía la cabeza de las modelos originales por otras de conocidas actrices de la farándula patria:

[el] Sr. Martínez Campos, practicó ayer un registro en una casa de la calle de Chinchilla, en la que encontró una copiosa colección de tarjetas postales totalmente reñidas con la moral y las buenas costumbres. [...] Este registro ha sido motivado por una denuncia presentada ante el Juzgado de guardia por dos conocidas artistas que actúan en uno de los teatros de Madrid de género chico. Fundamentaban ambas la denuncia en que desde hace algún tiempo venían circulando por Madrid unas tarjetas postales pornográficas en las cuales figuraban sus rostros recortados indudablemente de fotografías legítimas y superpuestos en la reproducción. [...] El Juzgado se incautó de un baúl lleno de postales, fotografías y una cámara fotográfica ${ }^{84}$.

De todos los géneros sicalípticos serían las postales eróticas las que revolucionarían la pornografía al consolidar la comercialización y distribución masiva del sexo como experiencia visual. Aunque, en general, las postales eróticas eran un producto callejero y asequible ${ }^{85}$, no faltaron los anuncios velados en las revistas licenciosas que, bajo los títulos de "escenas curiosas", "fotos secretas de París" o "comercio privado" ${ }^{6}$, ofrecían el envío discreto de estos materiales para satisfacer cualquier tipo de demanda:

Estas fotografías y tarjetas postales representan escenas de onanismo, masturbación, safismo y tribadismo, sodomía, homosexualismo, bestialidad, incesto, sadismo y masoquismo, deshonestidad con los niños, pequeña necrofilia, orgías, estupros, violaciones y, en fin, cuantas manifestaciones absolutamente inmorales puede sugerir la fantasía de un pervertido sexual ${ }^{87}$.

En conclusión, los cambios políticos y sociales favorecieron una relajación en la moralidad, si bien la relación que mantuvo la sociedad española con el cuerpo y el erotismo continuaba estando polarizada. La explotación comercial de los desnudos femeninos en revistas colisionó con los sectores más tradicionales que, de la mano de la Iglesia, aspiraron a contrarrestar sus aciagas consecuencias ${ }^{88}$. El prolífico mercado de la sicalipsis española se sostuvo en ese complicado equilibrio entre la condena moral y la circulación popular, hasta que se impuso el silencio de la censura franquista. El fenómeno del destape español no se volvería a recuperar hasta 40 años después, centrado ya en el cine como medio de difusión erótico por excelencia.

82 P. López, Historia de la fotografía..., p. 74.

83 M. Lucenay, La pornografía..., p. 49.

84 ABC, Madrid (21-V-1909), p.12.

85 El precio rondaba las 10 pesetas por colecciones que incluían unas 50 fotografías y las 50 pesetas por colecciones de 200, véase: Revista Muchas Gracias (26-XII-1931), 408, pp. 47-48.

86 Revista Muchas Gracias (20-II-1932), 415, p. 4.

87 M. Lucenay, La pornografía..., p.47.

88 "La Editorial Católica Gráfica S. A. ha propuesto dotar a nuestro público de una gran revista gráfica semanal que contrarreste en lo posible la ola de pornografía con que se viene envenenado a la juventud española desde las páginas gráficas de nuestras revistas", en La Verdad de Murcia (27-XII-1935), p. 7. 


\section{A MODO DE CONCLUSIÓN}

Que la pornografía interesase en todas sus vertientes —literaria, visual o artísticano deja de ser una respuesta social subversiva al dogma moral imperante aquellos años. El advenimiento de la Segunda República prometía traer consigo renovados aires de cambio que, en el ámbito sexual, prescindirían de las restricciones impuestas por el gobierno de la dictadura de Primo de Rivera. Nada más lejos de la realidad, pues solo dos meses después de la proclamación del nuevo gobierno republicano, la postura frente a la pornografía siguió la línea marcada por la dictadura:

[el Sr. Companys] dio cuenta de que la Policía había dado una batida por los quioscos de periódicos, recogiendo una gran cantidad de publicaciones pornográficas. En este asunto está dispuesto a proceder con la mayor energía, clausurando aquellos quioscos que reincidan en la venta de esas publicaciones. Respecto a los cafés-concerts, en los que algunas artistas dan, por imposición de los dueños, exhibiciones inmorales, el gobernador ha impuesto multas de 50 y 75 pesetas a varios de aquéllos, y también procederá con energía para poner coto a estas extralimitaciones ${ }^{89}$.

La ingente oferta erótica española tuvo como respuesta abundantes sanciones a quiosqueros, librerías, fotógrafos y cines. En Barcelona, señalada por Lucenay como "uno de los centros de importación más conocidos por la policía de costumbres en toda Europa" el gobernador civil llegó a ordenar en 1932 la creación de una brigada espacial contra la pornografía ${ }^{91}$, que velase por el control de escaparates, espectáculos y puestos callejeros. España vivió su apogeo sicalíptico al tiempo que el estrecho corsé de la moralina patria no consiguió aflojar las limitaciones y prejuicios de una sociedad fuertemente enraizada en el tradicionalismo. Sobre el papel, la Segunda República había conseguido avanzar en derechos sociales, educación y libertades individuales, pero el traslado de esta novedosa legislación a la cotidianidad de la vida pública y privada se vio frustrado por la persistencia de una mentalidad heredada de épocas pasadas. El análisis de este capítulo de nuestra historia permite descubrir una España interesada en el sexo como objeto científicoacadémico y como mercancía erótica; una España irreverente y verde frente a la contención moral dominante que convivió con estas expresiones hasta que fue redirigida nuevamente por el sendero único de la castidad y el puritanismo con la irrupción del régimen franquista.

\section{BIBLIOGRAFÍA}

Aguado, A., "Entre lo público y lo privado: sufragio y divorcio en la Segunda República", Ayer, 60, (2005), pp. 105-134.

Álvarez, R., "El Instituto de Medicina Social, primeros intentos de institucionalizar la eugenesia", Asclepio: Revista de historia de la medicina y de la ciencia, 40, (1988), pp. 343-358.

Amezúa, E., "La línea política de la reforma sexual. Memoria histórica y planes de futuro", Anuario de Sexología, 8, (2004).

- "Los hijos de don Santiago. Paseo por el casco histórico de la sexología", Revista Española de Sexología, 59-60, (1993).

89 "La campaña antipornográfica" en $A B C$ Madrid (13-V-1931), p. 27.

90 M. Lucenay, La pornografía..., p. 47.

91 "Anoche el gobernador dijo a los periodistas que había multado a varios dueños de kioscos de periódicos de las Ramblas por vender publicaciones de carácter pornográfico. (...) y manifestó, por último que había dispuesto la creación de Una brigada especial de policía para la persecución de la pornografía, en "Contra la pornografía" en La Vanguardia (21-VIII-1932), p. 6. 
- "Cuestiones históricas y conceptuales. El paradigma del hecho sexual, o sea de los sexos, en los siglos XIX y XX", Anuario de Sexología, 4, (1998), pp. 5-19.

Arcand, B., El jaguar y el oso hormiguero. Antropología de la pornografía, Buenos Aires, Nueva Visión, 1993.

Bandrés, J., Zubieta, E., Llavona, R., "Mujeres extraviadas: psicología y prostitución en la España de posguerra", Universitas Psychologica, 13, (2014), pp. 1667-1679.

Barrachine, M. A., "Maternidad, feminidad, sexualidad. Algunos aspectos de las Primeras Jornadas Eugénicas Españolas", Hispania, 218, (2004), pp. 1003-1026.

Blas, J., "La novela corta erótica española: noticia bibliográfica", Los territorios literarios de la historia del placer: I Coloquio de Erótica Hispana, 1996.

Burdiel, I., Los borbones en pelota, Institución Fernando el Católico, 2012.

Castejón, R., "Marañón y la identidad sexual: biología, sexualidad y género en la España de la década de 1920", Arbor, Ciencia, Pensamiento y Cultura, 759, (2003).

Cleminson, R., Anarquismo y sexualidad en España, 1900-1939, Universidad de Cádiz, Cádiz, 2008.

Cubero, C., La pérdida del pudor: el naturismo libertario español (1900-1936), Madrid, LaMalatesta, 2015.

Cura González, M. del y Huertas García-Alejo, R., "Medicina y sexualidad infantil en la España de los años treinta. La aportación del psicoanálisis a la pedagogía sexual", Hispania, 218, (2004), pp. 987-100.

Daza, J., "La ley de divorcio de 1932. Presupuestos ideológicos y significación política", Alternativas. Cuadernos de Trabajo Social, 1, (1992), pp. 163-175.

Diego, C., "La educación sexual en la escuela primaria: intento frustrado de los eugenistas", Cuestiones de género: de la igualdad y la diferencia, (2014), pp. 158-181.

Figari, C., "Placeres a la carta: consumo de pornografía y constitución de géneros", La ventana. Revista de estudios de género, 3, (2008), pp. 170-204.

Foucault, M., Historia de la sexualidad. La voluntad de saber, Buenos Aires, Siglo XXI, 2006. Garat, J. M., "En Cataluña existe ya el aborto legal", Mundo Gráfico, 1332, (1937), p. 5-6.

González, A., "Sobre los orígenes de la psiquiatría franquista: la psicopatología de guerra de J. J. López Ibor" en F. González (coord.), Ciencia y técnica entre la paz y la guerra: 1714, 1814, 1914, (2016), pp. 563-569.

Guereña, J. L., (coord.), La sexualidad en la España contemporánea (1800-1950), Cádiz, Universidad de Cádiz, 2011.

- Un infierno español. Un ensayo de bibliografía de publicaciones eróticas clandestinas españolas (1812-1939), Madrid, Libris, 2011.

- Detrás de la cortina. El sexo en España (1790-1950), Madrid, Cátedra, 2018.

- El sardinista pornógrafo, Ed. Renacimiento, 2019.

- "El burdel como espacio de sociabilidad", Hispania, 214, (2003), pp. 551-570.

Guillén, C., El Patronato de Protección a la Mujer: prostitución, moralidad e intervención estatal durante el franquismo, tesis doctoral dirigida por Carmen González y Encarna Nicolás, Universidad de Murcia, 2018.

Huertas, R. y Novella, E., "Sexo y modernidad en la España de la Segunda República. Los discursos de la ciencia", Arbor Ciencia, Pensamiento y Cultura, 764, (2013).

Kendrick, W., El museo secreto, Bogotá, Tercer Mundo, 1995.

León, A., “¿Disidencia dentro del feminismo?”, Revista Internacional de Sociología, 3, (2009), pp. 559-588.

Litvak, L., Antología de la novela corta erótica española de entreguerras, 1918-1936, Madrid, Taurus, 1994. 
Llona, M., "Los otros cuerpos disciplinados. Relaciones de género y estrategias de autocontrol del cuerpo femenino (primer tercio del siglo XX)", ARENAL, 14, (2007), pp. 79-108.

López, P., Historia de la fotografía en España. Fotografía y sociedad desde sus orígenes hasta el siglo XXI, Barcelona, Lunwerg, 2007.

Lucenay, M., La pornografía, Madrid, Editorial Fénix, 1933.

Marañón, G., Tres ensayos sobre la vida sexual, Madrid, Biblioteca Nueva, 1926.

Masjuan, E., La ecología humana en el anarquismo ibérico: urbanismo «orgánico»o ecológico, neomaltusianismo y naturismo social, Barcelona, Icaria, 2000.

Monferrer, J., "Serrano Vicens: el Kinsey español", en R. Osborne, Mujeres bajo sospecha: memoria y sexualidad (1930-1980), Madrid, Fundamentos, 2012, pp. 218-232.

Mora, V., Al margen de la naturaleza. La persecución de la homosexualidad durante el franquismo, Madrid, Ed. Debate, 2016.

Nash, M., "Aproximación al movimiento eugénico español: el Primer Curso Eugénico Español y la aportación del Dr. Sebastian Recassens", Gimbernat, Revista Catalana d'Història de la Medicina i de la Ciencia, 4, (1985).

Navarro, F. J., El paraíso de la razón. La revista Estudios 1928-1937 y el mundo cultural anarquista, Valencia, Institución Alfonso el Magnánimo, 1997.

Noguera, E. y Huerta, L., (coord.), Libro de las Primeras Jornadas Eugenésicas Españolas: Programa. Ponencias. Genética, eugenesia y pedagogía sexual, Madrid, Javier Morata, 1934.

Paz y J Montero, M., "Las películas censuradas durante la Segunda República. Valores y temores de la sociedad republicana española (1931-1936)", Estudios sobre el Mensaje Periodístico, 369, (2010), pp. 369 - 393.

Preciado, P. B., "Museo, basura urbana y pornografía", Zehar: revista de Arteleku-ko aldizkaria, 64, (2008), pp. 38-67.

Rámila, J., "Hildegart Rodríguez: La historia que conmocionó a la II República Española" Quadernos de criminología, 18, (2012), pp. 8-19.

Ricci, E., "La ola verde en la prensa y en los espectáculos en la II República", en J. M. Desvois (coord.), Prensa, impresos, lectura en el mundo hispánico contemporáneo, Université Michel de Montaigne Bordeaux, 2005.

Rodríguez, H., El problema eugénico. Punto de vista de una mujer moderna, Madrid, Gráfica Socialista, 1930.

- La limitación de la prole: un deber del proletariado consciente, Madrid, Gráfica Socialista, 1930.

- Sexo y amor; La revolución sexual, Valencia, Cuadernos de Cultura 41, 1931.

- El problema sexual tratado por una mujer española, Madrid, Javier Morata, 1931.

- Educación sexual, Madrid, Gráfica Socialista, Madrid 1931.

- Malthusismo y Neomalthusismo. El control de la natalidad, Madrid, Javier Morata, 1932.

Rodríguez, M., Prácticas postporno en el Estado español. Políticas y estéticas de representación y acción, tesis doctoral dirigida por Emilia María Durán Almarza, Universidad de Oviedo, 2017.

Roglan, J., La Barcelona erótica, Barcelona, Angle, 2003.

Romero, D., "XXX Pensar la pornografía", El Artista, 6, (2009), pp. 102-117.

Seoane, J. B., "Escuela, higiene y sexualidad infantil" en J. Mainer, Pensar críticamente la educación escolar: perspectivas y controversias, Zaragoza, Universidad de Zaragoza, 2008.

Sobreques i Callico, J., "Cataluña tuvo durante la República la ley del aborto más progresista 
de Europa" El País (13- II-1983).

Soldelvilla, J., Psicalíptics. Erotisme i trangressió a les revistes ilustrades del principi del segle $X X$, Barcelona, Museu d'Art de Sabadell.

Vallejo-Nájera, A., Eugenesia de la Hispanidad y Regeneración de la Raza, Burgos, Editorial Española, 1937.

Vázquez, F. y Moreno, A., Sexo y Razón. Una genealogía de la moral sexual en España (XVI-XX), Madrid, Akal, 1997.

Vicente, L., "Republicanismo, Anarquismo y Revolución Sexual: El magma de ideas en que nació Hildegart Rodríguez", Libre pensamiento, 82, (2015), pp. 52-59.

Zubiarre, M., Culturas del erotismo en España (1898-1939), Madrid, Cátedra, 2015. 